\title{
Modelling Alternatives for Highland Soil Structural Degradation and Erodibility, Bui Plateau, Cameroon
}

\author{
Reeves M. Fokeng, Zephania N. Fogwe, and Nadine T. Yemelong
}

\section{ABSTRACT}

Highland triggers of soil physical degradation through the fragilisation of soil aggregates are primarily factors of soil biochemistry and anthropogenic mishandling of land resources. Soil degradation forms are challenging the sustenance of human systems on earth. This study probes into soil physical degradation and exposure to external stressors using 60 soil samples collected and analysed for soil aggregate stability, vulnerability and erodibility to determine soil structural stability/resilient capacity. The soils were found to be stable in structure, but highly vulnerable to stress and erodible. Coarse-granitic sandy soils just as the less evolved erosion soils of the eastern slopes of the plateau were proven to be most erodible and vulnerable to physical degradation. Soil Structural Stability Index (ISS) was very low $(\leq 4.3 \%$ : severe physical degradation) for disturbed soils under grazing with similar tendencies on cultivated humid volcanic soils. High erosion vulnerability/erodibility soils are indicative of low organic matter and organic carbon content issuant of heavy and uncontrolled grazing, annual biomass burning and long-term cropping without soil improvement schemes which calls for guided land use practices over the Bui Plateau.

Keywords: Soil degradation, soil erosion, soil erodibility, Soil organic Carbon, Bui Plateau.

\section{INTRODUCTION}

Soils are fundamental to life on Earth but human pressures on soil resources are reaching critical limits [1]. Careful soil management is one essential element of sustainable agriculture and also provides a valuable lever for climate regulation and a pathway for safeguarding ecosystem services and biodiversity [2]. Physical land degradation involves the displacement and/or repositioning of soil particles without altering their chemical composition [3]. Soil degradation is a temporary or permanent lowering of the productive capacity of soil caused by overgrazing, deforestation, inappropriate agricultural practices, over exploitation of fuel wood leading to desertification and other man-induced activities [4]. Degradation as such is portrayed by physical, chemical, and biological soil depletion mechanisms. Outstanding physical processes are the decline in soil structure, crusting, compaction, erosion, desertification, environmental pollution, and unsustainable use of natural resources [5]. Major chemical processes are acidification and leaching, salinization, reduction in CEC and loss of fertility, biological processes on the other hand include reduction in total and biomass carbon, as well as the decline in soil biodiversity [5]. Erosion-induced soil degradation is initiated as a result of a decline in soil structure (compaction, crusting and loss of rooting depth and carbon and fertility [6]. Africa [11].
Published Online: November 30, 2020

ISSN: $2684-446 \mathrm{X}$

DOI : 10.24018/ejgeo.2020.1.6.84

\section{R. M. Fokeng*}

Department of Geography and Planning, Faculty of Arts, The University of Bamenda, Cameroon.

(e-mail: rfokeng@yahoo.com)

Z. N. Fogwe

Department of Geography and Planning, Faculty of Arts, The University of Bamenda, Cameroon.

(e-mail: nfogwez@gmail.com)

Nadine T. Yemelong

Department of Geography, HTTC, The University of Bamenda, Cameroon. (e-mail: nyemelong @yahoo.com)

*Corresponding Author

plant available water) as well as a decline in soil organic

While the global food production is increasing, agrarian land is degrading rapidly, jeopardizing future prospects [7]. Soil erosion, chemical deterioration and physical degradation are parts amongst various types of soil degradation [8] that affect water infiltration into the soil by (i) reducing vegetation cover (ii) exposing less permeable soil layers through erosion, and (iii) rupturing soil structure including through the loss of soil organic matter [9]. Soil degradation is a rising menace to food security, as it forces farmers to use more inputs, and may eventually lead to soil abandonment [10]. Yield reduction due to past soil erosion may range from 2 to $40 \%$, with a mean loss of $8.2 \%$ for

The health of soils is gaining needed attention, most notably in its inclusion into the Sustainable Development Goals (under target 15.3: Land Degradation Neutrality) as well as the other global targets set under the United Nations Convention to Combat Desertification [7]. The stability of aggregates in the surface soil is crucial to the processes of soil erosion and runoff generation in agricultural lands [12]. Soil erosion risk has been widely assessed based on rainfallrunoff erosivity, soil erodibility, and erodability (terrain characteristics) using the Universal Soil Loss Equation and its family of models. Soil erodibility is a key parameter in 
erosion prediction and is important for conservation planning in the wake of arising need for protecting the limited land resources [13].

Assessment of soil exposure to external stressors and ensuing degradation is of prime importance to the implementation of Sustainable Land Management (SLM) strategies. Some significant number of studies on land degradation on the Western Highlands of Cameroon have variably been limited to diagnosis of the cause-effect analysis of watershed-forest degradation as provoked by man [14]-[17] and soil erosion [18]. Fewer studies investigated soil erodibility and structural stability as a proxy-indicator of soil physical degradation in the Western Highlands like the works of [19] over the Southern Bamileke Plateau and [20] for cultivated soils of Foumbot. Studies on soil erodibility of permanently grazed Bamenda Highlands are lacking with only [21] for the Santa toposequence. The Bui Plateau is a knowledge void area about the status of soils yet ripe with soil degradation processes over time and space even in the most inaccessible areas. This study seeks to understand, using techniques of Geographical Information Systems, the physical degradation processes occurring at watershed scale and across pastoral systems of the Southern Bui Plateau, Western Highlands of Cameroon.

\section{THE STUDY AREA}

The Bui Plateau within the Bamenda Highlands presents a topographic variation with heights ranging from about $700 \mathrm{~m}$ above sea level (asl) around the Wasi-Ber and Mbaw Plains to $3011 \mathrm{~m}$ (asl) culminating at Mount Oku. The Plateau lies along the Cameroon Volcanic Line (CVL) and the Western Cameroon Highlands in its north western extension (Bamenda Highlands). To the northeastern direction, the plateau extends to the Nkambe High Plateau, to the northwest it extends to the Konene-Lassin Low Plateau, to the west it forms a continuity with the Oku-Kom Highlands, to the south west, it terminates into the Ndop and Wasi-Ber Plains of the Upper Nun Valley, to the south, the plateau forms a tongue-like elevated extension culminating at Mount Mbam (2000 m asl) and to the southeast it topples to the Mbaw Plain that extends to the Tikar and Mbam Plains (Fig. 1).

In its spatial delimitation, the South Bui Plateau cuts across the central limits of the plateau to western and eastern limits with the Kom Highlands and Mbaw Plains respectively and its southern extension or southern tongue; the Mount Mbam. [22], based on the Köppen's 1936 climatic classification, it is established that the Bui Plateau corresponds to the 'Aw' climate type, with two seasons (dry and wet). The dry season lasts for four to five months (November to March) while the wet season lasts for eight months (March/April to October). The climate together with the soils, dominantly iron and aluminum-rich has given rise to savanna grassland in majority interspersed with dotted montane shrubs and forest refugia. Important montane forest remnant can be found on Mount Oku and Mount Mbam showing characteristics of long-term anthropogenic degradation. The maintained grasslands are also a relic of long-term colonization of the hillslopes of the South Bui
Plateau by cattle herders. This is due to the adjacency of the Wasi-Ber, Ndop and Mbaw Plains to the southern extension of the plateau used as dry season transhumant grazing zones. Land degradation (soil and vegetation) is very visible in the two main localities of Lip in Jakiri and Mbiame local council areas. Administratively, the South Bui Plateau covers four municipalities (Lower Mbiame and Kumbo, Oku and Jakiri).

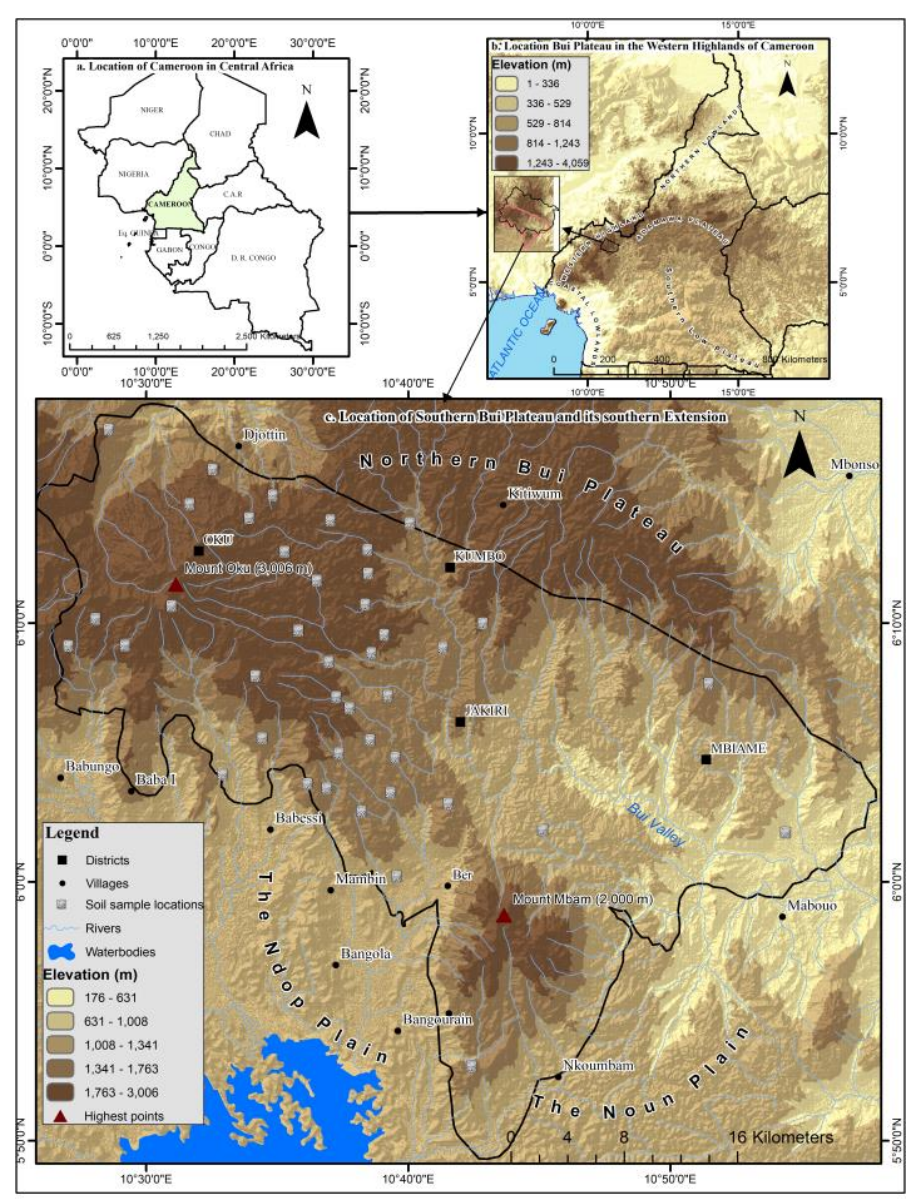

Fig. 1. Map of the Southern Bui Plateau in the Western Highlands of Cameroon.

According to [23], the study area comprises of volcanic soils (humid soils of high lava plateau and soils on low lava basalts), granitic coarse-sandy and fine-textured soils.

\section{MATERIALS AND METHODS}

FAO [24] established practical guidelines for field soil sampling. It recommended that within a stratum, the sampling locations where soil cores are taken should be determined randomly to avoid bias. However, certain areas shall be excluded in grazed lands, such as patches with animal excreta, animal pathways, driveways to enter/leave fields, very near watering points [24]. Soil samples were randomly collected for the studied sites following land cover/use to take care of the possible variation of soil properties with land-surface spatial heterogeneity. Each soil sample was made up of four soil cores which were combined to form a composite sample for analysis. Compositing (or bulking) several soil cores or subsamples to make a composite sample was recommended to estimate SOC content in soils by [24]. Soil physicochemical variables 
have been widely reported from $0-20 \mathrm{~cm}$ soil depth. IPCC recommended a depth of $0-30 \mathrm{~cm}$ if soil parameters like SOC were to be analyzed. A total of 60 soil samples were collected at 0-30 cm (0.3 m) soil depth for the study (Fig. 1). Collected soil samples were air dried for 5 days before grinding and sieving for use in laboratory analysis at the Laboratory of Soil Analysis and Chemistry of the Environment (LABASCE) of the Faculty of Agronomy and Agricultural Sciences, University of Dschang, Cameroon. 2mm sieve was used to obtain soil separates or particle sizes (percent sand, silt, and clay). The organic carbon concentrations of soil samples were determined by applying the dichromate oxidation method proposed by [25]. A conversion factor of 1.724 was used to convert soil organic carbon (SOM) to organic matter (SOM) as recommended.

The GPS coordinates of each sampling location was collected to enable geostatistical soil analysis and spatial interpolation. For interpolating soil properties - which vary not only with distances but also with direction - a method which assigns weights to the values of sampled points based on distances as well as the direction would be preferable [26]. The inverse distance weighting (IDW) method estimates the values of an attribute at unsampled points using a linear combination of values of sampled points weighted by an inverse function of the distance from the point of interest to the sampled points [27] and so was used in the spatial modelling of soil attributes and degradation indices.

For the estimation of soil structural degradation and erodibility, aggregate stability measures the structural stability of soils [4], and/or the ability of soil aggregates to withstand breakdown to small fragments when quickly moistened [28]. Factors that influence aggregate stability are important in evaluating the ease with which soils erode by water and/or wind, the potential of soils to crust and/or seal, soil permeability, quasi-steady state infiltration rates and seedling emergence and in predicting the capacity of soils to sustain long-term crop production [4]. Apart from quantitative indices for soil erodibility to estimate soil erosion some other indices are also used by researchers to understand the proneness of soil to erosion [29]. The soil aggregate stability index (ISS) developed by [30] have been widely used to assess soil structural degradation. Soil erodibility which is a measure of soils susceptibility to erosion has been widely estimated using the Universal Soil Loss Equation of [31] and/or the Revised Universal Soil Loss equation by [32]. Besides this, other erodibility indices include Clay Ratio (CR) [33], [34], Modified Clay Ratio (MCR) [35] and Critical Level of Soil Organic Matter (CLOM) [30]. We used the ISS to assess soil structural degradation, the Erosion/Productivity Impact Calculator (EPIC) soil erodibility estimator [36] to estimate soil erodibility and Critical level of soil organic matter (CLOM) [30] to assess soil susceptibility to erosion over the Plateau.

For the soil Aggregate Stability Index (ISS), [37] developed a soil crusting index for measuring the risk of soil structural degradation linked to crusting. This is based on soil organic matter content and percent clay and silt as expressed in Equation 1.

$$
I S S=\frac{O M(\%) \times 100}{\operatorname{Clay}(\%)+\operatorname{Silt}(\%)}
$$

where ISS is the soil crusting index, OM is the percent organic matter. For numerous savannah soils of West Africa, [37] distinguished the following critical values of ISS: ISS < 5\% indicates severe physical degradation; ISS < $5 \%<7 \%$ implies high hazards of physical degradation; $7 \%$ $<$ ISS $<9$ implies low risk of physical degradation; $9<$ ISS indicates no physical degradation and soils with adequate SOM to maintain stability. Pieri [30] later modified the ISS by using soil organic carbon as a substitute to measure soil risk to structural degradation and aggregate stability based on soil organic carbon content (Equation 2).

$$
I S S=\frac{1.724 \times O C}{(L+A)} \times 100
$$

where OC is the soil organic carbon, L is the silt fraction, and $\mathrm{A}$ is the clay fraction. An ISS $>9 \%$ indicates stable structure with sufficient SOC to main structural stability, $7 \%$ $<$ ISS $\leq 9 \%$ indicates low risk of structural degradation, $5 \%$ $<$ ISS $\leq 7 \%$ indicates high risk of degradation, and ISS $\leq 5 \%$ indicates structurally degraded soil.

For Soil Erodibility (K), the direct measurements of erodibility factor are both costly and time consuming and has been feasible only for a few major soil types [31]. The USLE-K factor estimate has become the most popular and well-accepted soil erodibility calculation method [38]. The K-value based on basic soil property variables can be expressed in mathematical terms [39], [31] based on a nomograph regarding particle size (percent silt), percent of organic matter, soil structure and profile permeability as in Equation 3.

$$
K=\left\lfloor 2.1 \times 10^{-4}(12-S O M) M^{1.14}+3.25\left(S_{t}-2\right)+2.5\left(p^{\prime}-3\right)\right\rfloor / 100
$$

where $\mathrm{M}$ represents a newly defined term, the product of the silt + very fine sand $(0.002-0.1 \mathrm{~mm})$ and $0.1-2 \mathrm{~mm}$ sand fractions (\%), $\mathrm{S}_{\mathrm{t}}$ and $\mathrm{P}^{\prime}$ are the soil structure and permeability class, respectively, and SOM, as mentioned above, is soil organic matter content (\%) [38]. Only two soil properties are needed in EPIC to calculate the soil erodibility K-value: the soil organic carbon content and soil particle size distribution [36] cited in [38] as in equation 4.

$K=\left(0.2+0.3 e^{[-0.02565 S A N(1-S L L 1 / 100)}\right) \times\left(\frac{S I L}{C L A+S I L}\right)^{0.3} \times\left[1-\frac{0.25 C}{C+e^{(3.72-2-295 C)}}\right] \times\left[1-\frac{0.7 S N_{1}}{S N_{1}+e^{\left(22.9 S N_{1}-5.51\right)}}\right]$

where SAN is the sand content (\%), SIL is the silt content $(\%)$, CLA is the clay content $(\%), \mathrm{C}^{\prime}$ is the soil organic carbon content $(\%)$, and $\mathrm{SN}_{1}=1-\mathrm{SAN} / 100$ [38].The $\mathrm{K}$-factor ranges from 1 (very easily eroded) to 0.01 (very stable soil).The EPIC soil erodibility estimator has been widely used in R/ULSE modeling due to its less data requirements, straightforwardness and efficiency in prediction. In this study, the K-factor was estimated using the algorithm of EPIC as in Equation 4.

Critical level of organic matter (CLOM) is also an 
indicator of erosion susceptibility [29]. Its estimation is based on [30], as in Equation 5.

$$
C L O M=\frac{O M}{\operatorname{Clay}(\%)+\operatorname{Silt}(\%)}
$$

If the value of CLOM is less than $5 \%$, it is indicated that soil loses its structure and becomes highly susceptible to erosion. Soil is said to be moderately susceptible to erosion if the value lies between 5 and 7\%. CLOM value more than $9 \%$ indicates that soil is stable and offer more resistance to erosion [30].

\section{RESUlTS AND Discussions}

\section{A. Soil Types, Attributes and Risk of Physical Degradation}

The soils of the South Bui Plateau are dominantly sandy $(>75 \%)$ across all land cover/uses. High sand content in soil increases soil fragility to erosion and soil loss as opposed to dominant silt and clay which bind soil aggregate into structure. The mean values for silt and clay across all land cover/uses were $13.09 \%$ and $11.28 \%$ respectively (Table 1 , Fig. 2 and 3). The degree of soil fragility based on soil physical parameters of sand, silt and clay and soil biological structural variable (soil organic carbon) is evaluated through the soil erodibility K-factor and CLOM.

\section{TABLE 1: MEAN VALUES OF SOIL PHYSICAL CHARACTERISTICS OF THE SOUTHERN BUI PLATEAU}

\begin{tabular}{lccccccc}
\hline \multicolumn{1}{c}{ Land cover/use } & Texture & No & $\begin{array}{c}\text { Sand } \\
(\%)\end{array}$ & $\begin{array}{c}\text { Silt } \\
(\%)\end{array}$ & $\begin{array}{c}\text { Clay } \\
(\%)\end{array}$ & $\begin{array}{c}\text { Organic } \\
\text { Carbon }(\%)\end{array}$ & $\begin{array}{c}\text { Organic } \\
\text { matter }(\%)\end{array}$ \\
\hline Eucalyptus forest & Loamy sand & 02 & 86 & 8.5 & 5.5 & 3.72 & 6.42 \\
Farmland & Sandy loam & 36 & 76.9 & 12.3 & 10.8 & 4.18 & 7.20 \\
Grazing land & Sandy loam & 14 & 68.7 & 15.7 & 15.6 & 3.62 & 6.24 \\
Degraded grazing land & Loamy sand & 01 & 80.0 & 17.0 & 3.0 & 0.50 & 0.86 \\
Abandoned farmland & Loamy sand & 01 & 81.5 & 12.5 & 6.0 & 5.76 & 9.92 \\
Improved grazing land & Loamy sand & 01 & 84.5 & 11.99 & 3.5 & 5.10 & 8.80 \\
Natural forest & Sandy loam & 04 & 77.5 & 12.25 & 10.25 & 4.86 & 8.38 \\
Catchment land & Loamy sand & 01 & 79.5 & 16.0 & 4.5 & 3.60 & 6.21 \\
Mean & Sandy loam & 60 & 75.61 & 13.09 & 11.28 & 4.05 & 6.98 \\
\hline \multicolumn{7}{c}{ Source: Fieldwork $(2020)}$. & \\
\end{tabular}
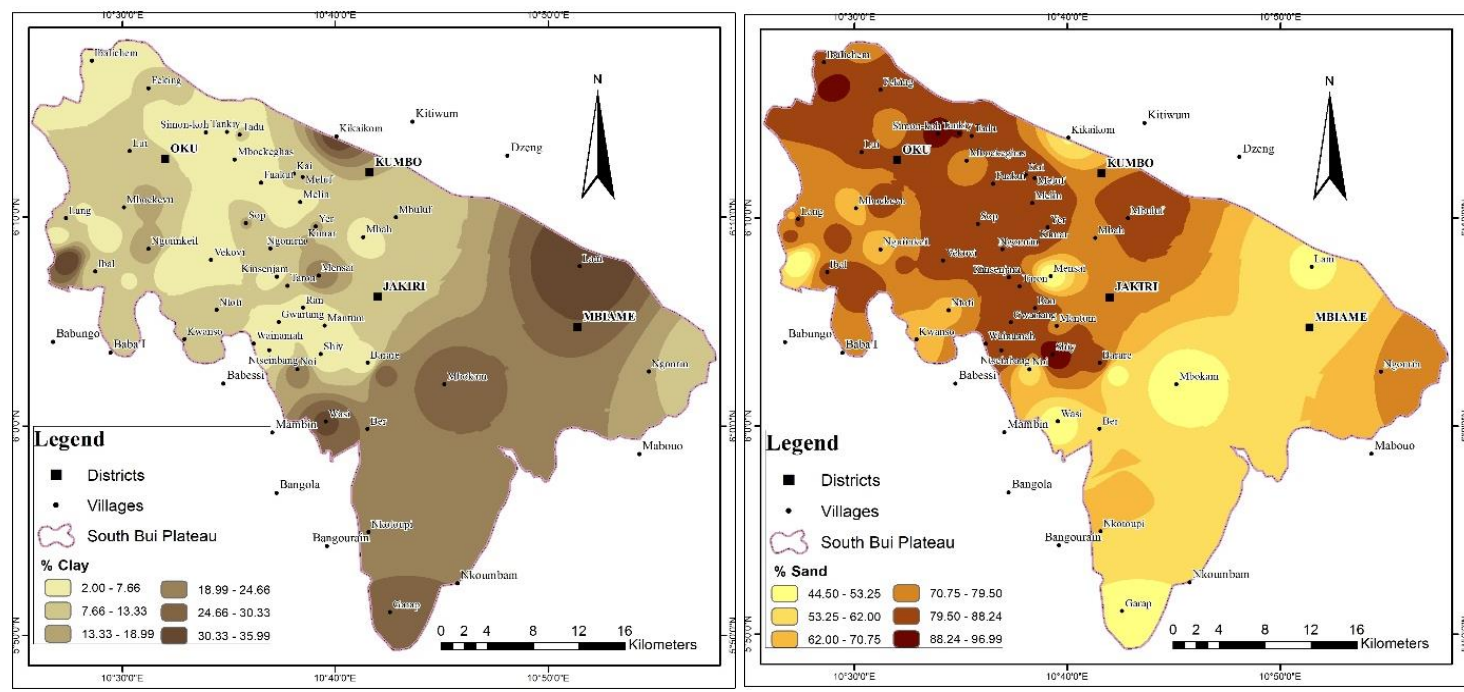

Fig. 2. Spatial variation of percent clay and sand over the southern Bui Plateau.

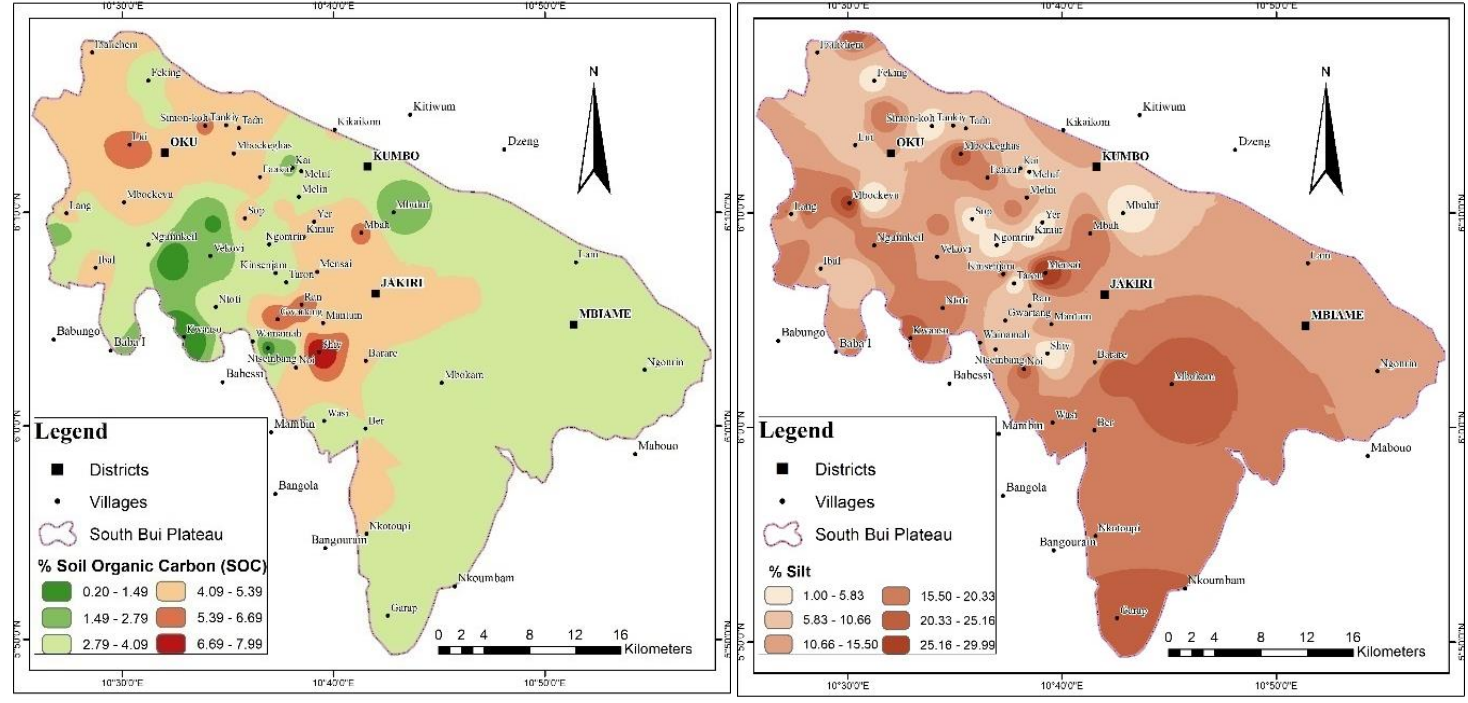

Fig. 3. Spatial variation of SOC and percent silts over the Southern Bui Plateau. 
SOC content of the soils are general low. The mean SOC (\%) across all land cover/uses was just $4.05 \%$. low SOC content is an indicator of poor soil health and degraded soils with less nutrient pool. The south-eastern slopes are associated with low SOC (0.20-1.49\%).

\section{B. Land Use Practices and Soil Physical Degradation Processes}

It is reported that the soils have near stable structures across the study area based on ISS. This explains a less likelihood of soil degradation by crusting, sealing and compaction. Whilst in majority the ISS index shows a near stable and resilient soil structure for some parts of the plateau, landscapes undergoing anthropisation and human misuse shows the weakening of soil resilience capacity and high risk of structural degradation as noted in [40]. This has been visible on poorly managed degraded grazing fields (ISS $=4.3 \% \leq 5 \%$ (severe physical degradation) currently undergoing soil compaction, nutrient depletion, soil biodiversity loss and tonnes of soil loss following heavy storm events and increase runoff (Table 2).

An ISS of $4.3 \%$ indicates a severe risk of physical degradation linked to destruction of soil structure by overgrazing and misuse of land. This involves mostly coarse-sandy granitic soils in the eastern section of the plateau (Fig. 4).

Other land use practices now said to be threatening soil aggregate stability (Plate 1.) and weakening of soils resistive capacity are farming and grazing (ISS $=23 \%$ and $19.9 \%$ respectively) as compared to (ISS $=53.62 \%$ and $57.14 \%$ for abandoned farmlands and managed grazing lands (ranch) respectively). This explains loss of soil vital elements like SOC and SOM responsible for structural stability by overcultivation, nutrient mining, and uncontrolled grazing (mostly associated with biomass burning and transhumant seasonality). A reduction in soil aggregate stability implies an increase in soil degradation [4]. The high values of ISS for abandoned farmlands and managed grazing lands are feedback signals for the need of SOC and SOM management and improvement to maintain healthy soils and landscapes.

Maximum SOC and SOM levels were reported from the two aforementioned land uses $(5.76 \%$ and $5.10 \%$ of SOC; $9.92 \%$ and $8.80 \%$ of SOM). This forms the bases for sustainable land management practices that aimed at improving SOC and SOM content of the soils to ensure healthy soils.

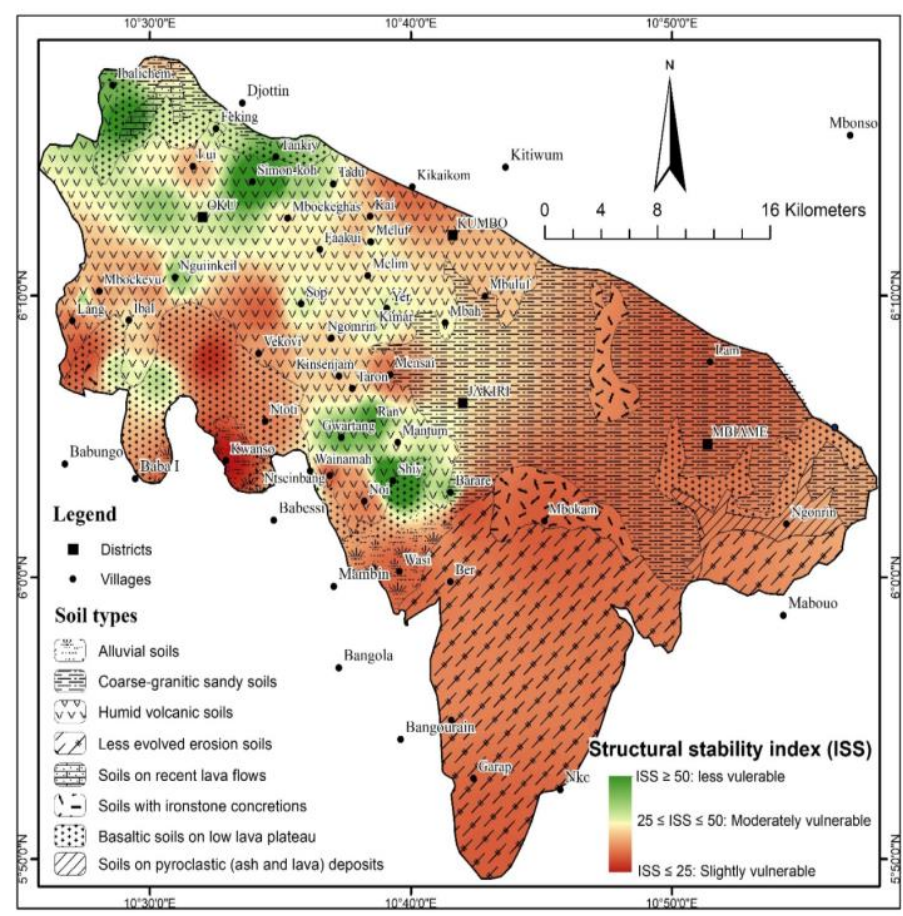

Fig. 4. Soil stability index and soil structural degradation vulnerability.

\begin{tabular}{lcccccccc}
\multicolumn{1}{c}{ TABLE 2: SOIL BIO-PHYSICAL PARAMETERS AND SOIL STRESS INDICES ACROSS LAND COVER/USES } \\
\hline \multicolumn{1}{c}{ Land cover/use } & $\begin{array}{c}\text { Sand } \\
(\%)\end{array}$ & $\begin{array}{c}\text { Silt } \\
(\%)\end{array}$ & $\begin{array}{c}\text { Clay } \\
(\%)\end{array}$ & $\begin{array}{c}\text { SOC } \\
(\%)\end{array}$ & $\begin{array}{c}\text { SOM } \\
(\%)\end{array}$ & ISS & CLOM & K \\
\hline Eucalyptus forest & 86 & 8.5 & 5.5 & 3.72 & 6.42 & 45.85 & 0.46 & 0.3 \\
Farmland & 76.9 & 12.3 & 10.8 & 4.18 & 7.2 & 23 & 0.31 & 1.86 \\
Stable grazing land & 68.7 & 15.7 & 15.6 & 3.62 & 6.24 & 19.9 & 0.19 & 0.34 \\
Degraded grazing land & 80 & 17 & 3 & 0.5 & 0.86 & 4.3 & 0.04 & 0.47 \\
Abandoned farmland & 81.5 & 12.5 & 6 & 5.76 & 9.92 & 53.62 & 0.54 & 0.36 \\
Improved grazing land & 84.5 & 11.99 & 3.5 & 5.1 & 8.8 & 57.14 & 0.56 & 0.34 \\
Natural forest & 77.5 & 12.25 & 10.25 & 4.86 & 8.38 & 36.83 & 0.36 & 0.37 \\
Catchment area & 79.5 & 16 & 4.5 & 3.6 & 6.21 & 30.29 & 0.3 & 0.42 \\
Mean & $\mathbf{7 5 . 6 1}$ & $\mathbf{1 3 . 0 9}$ & $\mathbf{1 1 . 2 8}$ & $\mathbf{4 . 0 5}$ & $\mathbf{6 . 9 8}$ & $\mathbf{3 3 . 8 6}$ & $\mathbf{0 . 3 5}$ & $\mathbf{0 . 5 6}$
\end{tabular}

TABLE 3: SOIL PHYSICAL DEGRADATION BIOPHYSICAL DETERMINANTS AND DEGRADATION MATRIX

\begin{tabular}{ccccccccc}
\hline & $\begin{array}{c}\text { Sand } \\
(\%)\end{array}$ & $\begin{array}{c}\text { Silt } \\
(\%)\end{array}$ & $\begin{array}{c}\text { Clay } \\
(\%)\end{array}$ & $\begin{array}{c}\text { SOC } \\
(\%)\end{array}$ & $\begin{array}{c}\text { SOM } \\
(\%)\end{array}$ & ISS & CLOM & K \\
\hline Sand (\%) & 1 & & & & & & \\
Silt (\%) & -0.54 & 1 & & & & & \\
Clay (\%) & $-0.86^{* *}$ & 0.04 & 1 & & & & \\
SOC (\%) & 0.11 & -0.56 & 0.20 & $1 *$ & & & \\
SOM (\%) & 0.11 & -0.56 & 0.20 & $0.99 * *$ & 1 & & \\
ISS & 0.56 & $-0.71 *$ & -0.24 & $0.84^{* *}$ & $0.84 * *$ & 1 & \\
CLOM & 0.55 & $-0.75^{*}$ & -0.20 & $0.87 * *$ & $0.86^{* *}$ & $0.96 * *$ & 1 & \\
K & -0.19 & -0.06 & 0.26 & 0.00 & -0.00 & -0.31 & -0.15 & 1 \\
\hline \multicolumn{7}{c}{$*$ Significant at 0.01 level (2-tailed) $*$ significant at 0.05 level (2-tailed). }
\end{tabular}



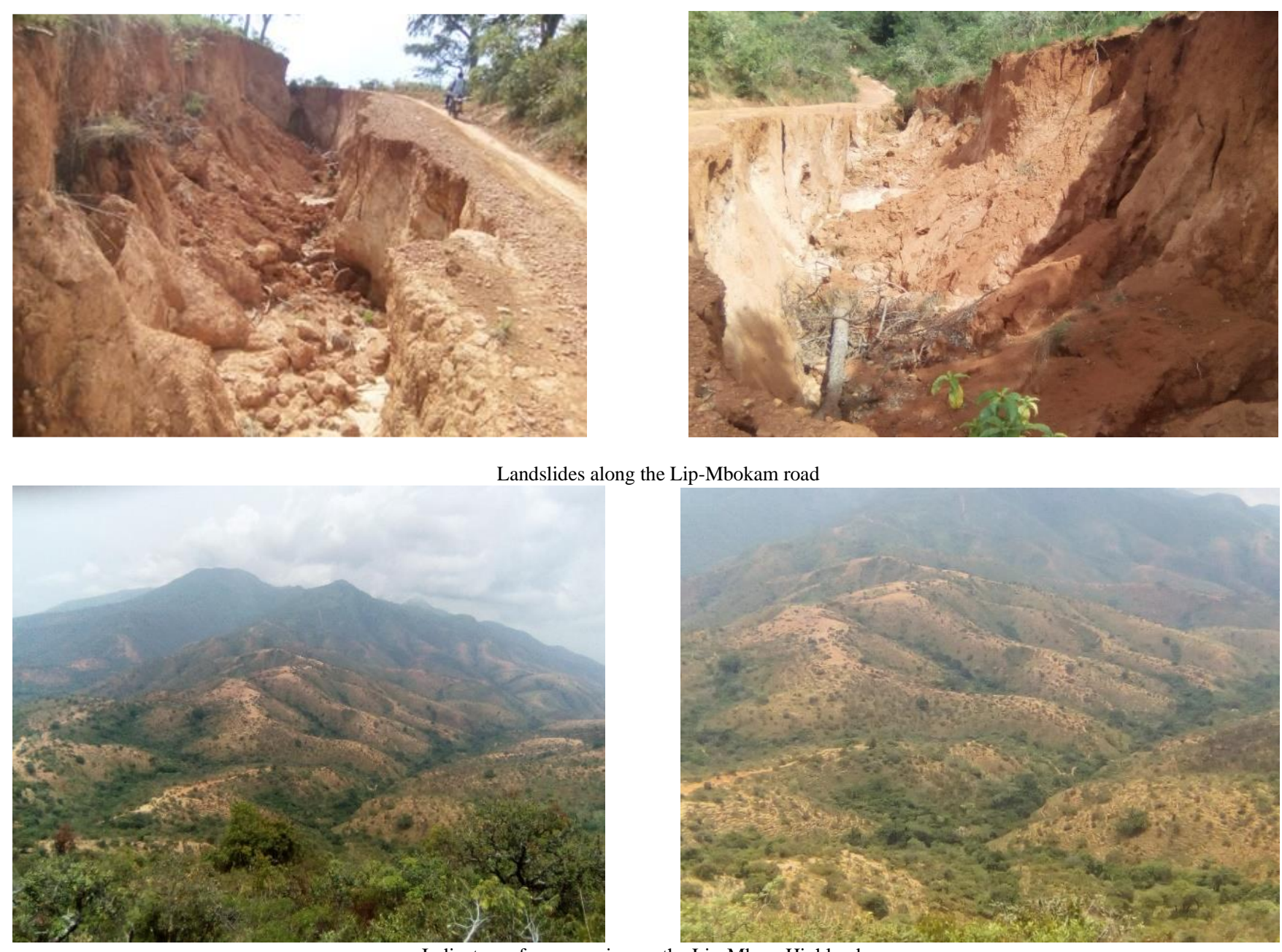

Indicators of over grazing on the Lip-Mbam Highlands

Plate 1. Process-response analysis of physical degradation over the Plateau.

C. Bui Plateau Soil Traits, Aggregate Stability and Degradation Indices

Several factors have been reported to determine soil aggregate stability and hence soil structural degradation. Amongst the main soil biophysical and chemical components have been soil separates (texture), SOC and SOM. Based on a single factor analysis, SOM or SOC can be used as an indicator of soil health and degradation (Table 3).

Sand is negatively correlated with clay $(\mathrm{r}=-0.86, \mathrm{p}=$ $0.003<0.01)$. Silt is negatively correlated with CLOM and ISS $(r=-0.75, p=0.019<0.05)$ and $(r=-0.71, p=0.033<$ $0.05)$, Organic carbon is positively correlated with SOM, ISS and CLOM $(r=0.99, p=0.000<0.01, r=0.87, p=$ $0.005<0.01$ and $\mathrm{r}=0.84, \mathrm{p}=0.003<0.01)$. SOM derived from SOC is normally correlated to it $(r=1)$, but also positively correlated with CLOM $(\mathrm{r}=0.86, \mathrm{p}=0.003<$ $0.01)$ and to ISS $(r=0.84, p=0.005<0.01)$. The ISS and CLOM were positively related $(\mathrm{r}=0.96, \mathrm{p}=0.000<0.01)$.

None of the soil parameters were strongly correlated with $\mathrm{K}$ (soil erodibility). There is weak negative correlation between $\mathrm{K}$ and ISS $(\mathrm{r}=-0.31)$, and between $\mathrm{K}$ and percent clay $(r=0.26)$. Acceptable levels of clay in the soil helps to bind soil particles into peds thereby reducing soil erodibility. The weak correlation of $\mathrm{K}$ with the selected soil physicochemical properties therefore revealed that ISS and CLOM are good predictors of soil structural stability and/or degradation and hence soil erosion susceptibility assessment. This explains the importance of SOC and SOM as the main parameters responsible for maintaining soil health and aggregate stability to reduce the risk of soil physical degradation. The SOM plays vital role in binding soil particles into aggregates of stable structure. The low level of SOC and SOM partly linked to unsustainable land use practices like biomass burning, overgrazing and overcultivation explains the weakening of the soil's resilient capacity to external stressors and the increase susceptibility to water erosion. In this respect, SOM explains tolerant limits for ISS and an early warning for sustainable SOM management to improve soil health and resilience. SOM is very beneficial for protecting soil from structural degradation.

\section{Soil Erodiblilty and Soil Erosion Susceptibility}

Soil erodibility a measure of the soil's proneness to water erosion hazards was assessed based on EPIC and the susceptibility of soil to this physical stressors assessed using percent critical organic matter (CLOM). The general soil texture (sandy loam) over the plateau is a factor explaining the high erodibility of the soils due to its very high sand content $(\geq 70 \%)$ making soil structure vulnerability to external stress. Topography and soil formation traits combine to increase this soil erosion risk (Fig. 5).

Based on CLOM, coarse-granitic sandy soils, humid volcanic soils and less evolved erosion soils at higher 
elevations are the most likely prone to erosion. This covers approximately $92.51 \%$ of the study area (Table 4); either $12578.6 \mathrm{~km}^{2}$. This includes very highly susceptible areas $\left(36.30 \%\right.$ or $\left.4936.04 \mathrm{Km}^{2}\right)$ and extremely susceptible areas $\left(56.21 \%\right.$ or $\left.7642.56 \mathrm{Km}^{2}\right)$.

\begin{tabular}{lcc} 
TABLE 4: SOIL EROSION SUSCEPTIBILITY CLASSES AND AFFECTED AREAS \\
\cline { 2 - 3 } \multicolumn{1}{c}{ Susceptible Classes } & Area $\left(\mathbf{k m}^{\mathbf{2}}\right)$ & Percentage \\
\hline Nearly stable to susceptible & 14.52 & 0.11 \\
Moderately susceptible & 26.01 & 0.19 \\
Highly susceptible & 976.93 & 7.19 \\
Very highly susceptible & 4936.04 & 36.30 \\
Extremely susceptible & 7642.56 & 56.21 \\
Total & $\mathbf{1 3 5 9 6 . 0 6}$ & $\mathbf{1 0 0}$ \\
\hline
\end{tabular}

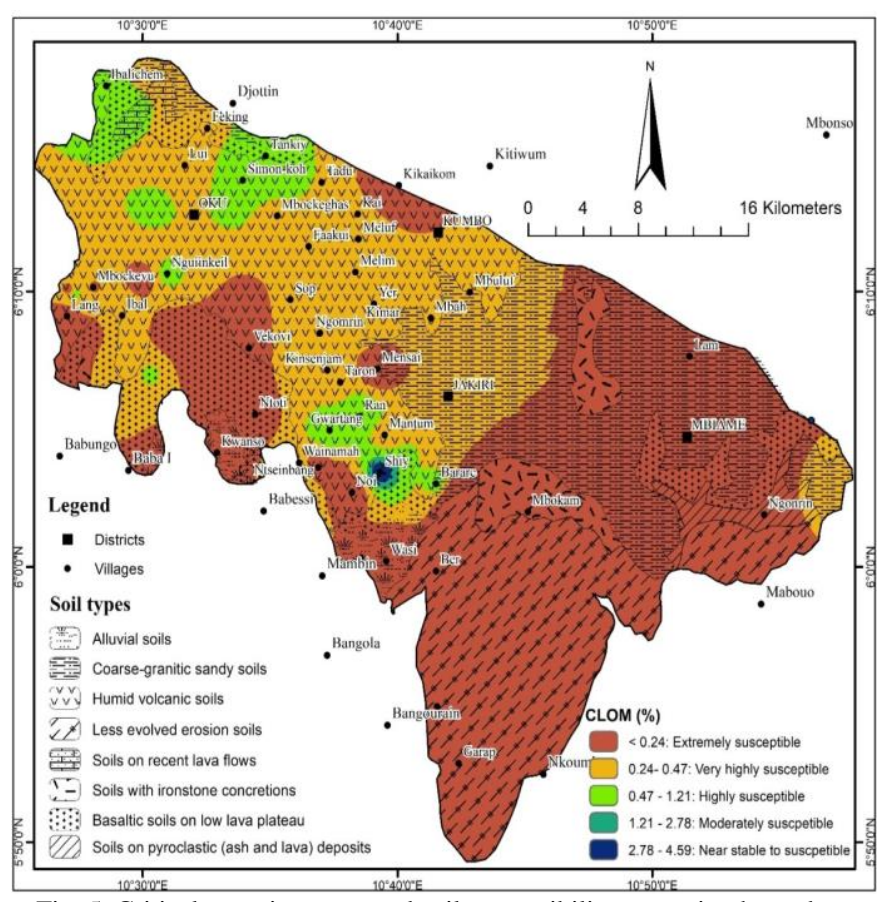

Fig. 5. Critical organic matter and soil susceptibility to erosion hazards.

The different soil types depending on SOM and SOC content shows varying erodibility. Over three quarters of the Bui plateau is subject to high and extreme erodibility as well as erosion vulnerability (Fig. 6.).

Less evolved erosion soils covering the Mbam Mountain range are the most erodible $(\mathrm{K}=+1)$. This is followed by coarse-granitic sandy soils $(K=0.98-1)$. Areas with slightly low soil erodibility are most covered by humid volcanic soils with high concentration of organic matter and stables soil structure. Controlling grazing over the south-eastern section of the plateau will be a great relief to the soil erosion threat. Less evolved erosion soils of the Mbam Mountains and coarse-granitic sandy soils of the Mbokam-Mbiame Range are highly erodible because of the high sand content and less organic matter to bind soil particles to form peds. The fragility of these soils and exposure to water erosion has been accelerated by heavy and uncontrolled grazing, associated with yearly biomass burning and vegetation depletion. Fire is said to increase event soil loss due to its increase soil bareness and runoff speed over land.

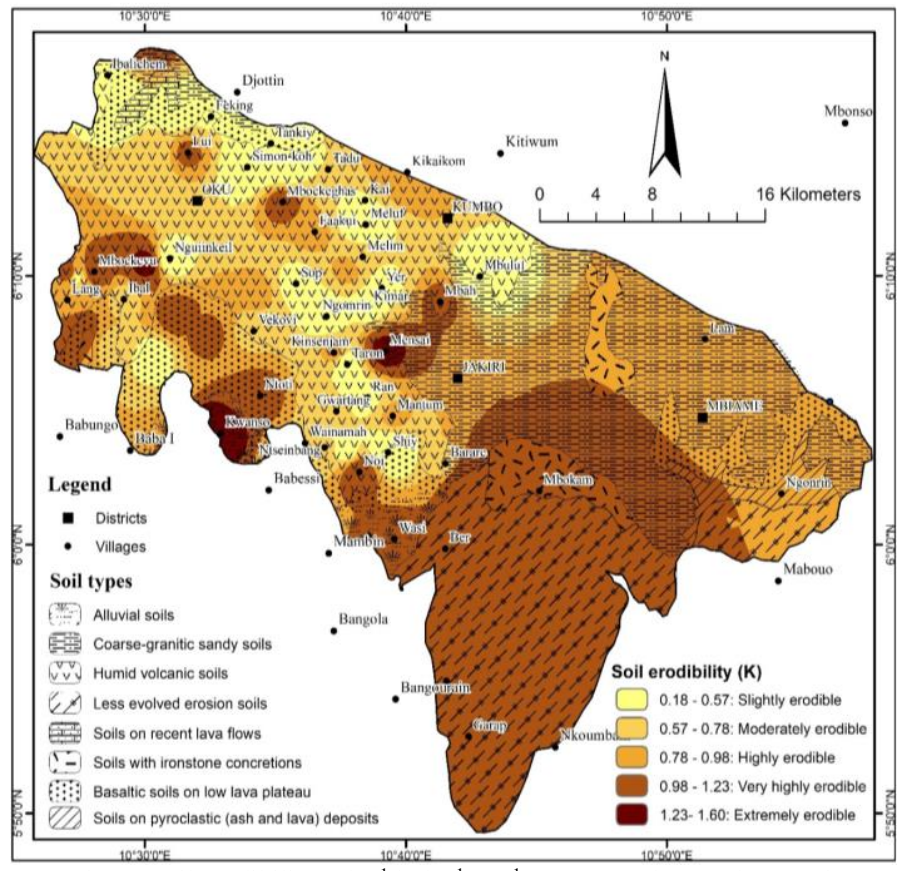

Fig. 6. Soil erodibility ( $\left.\mathrm{tha}^{-1} \mathrm{~h} / \mathrm{ha}^{-1} \mathrm{MJ}^{-1} \mathrm{~mm}\right)$ over the Southern Bui Plateau.

Soil aggregate stability is influenced by a number of factors including soil texture, clay mineralogy [28], SOM level, type and content of cations, contents of $\mathrm{Fe}-\mathrm{Al}$ oxyhydroxides and $\mathrm{CaCO}_{3}$, with multiple interactions among these properties capable of modifying their individual influence [41]. The two most important are SOM [12], especially in low-sodium soils [42], [43] and $\mathrm{Fe}-\mathrm{Al}$ oxides mainly in tropical and lateritic soils [44], [45]. In view of its role in soil aggregation and erosion control, in availability of plant nutrients and in ameliorating other forms of soil degradation than erosion, SOM has proven to be an important indicator of soil degradation [46]. After particle size distribution of soils, SOM ranks next as an indicator of soil erodibility [47], the proneness of soil to erosion. The Universal Soil Loss Equation (USLE) and other erosion prediction models developed from it show the importance of SOM in soil erosion prediction. The severity of soil erosion by water is intricately linked to SOM concentration [48], and so could be estimated from SOM by calibration involving matching possible range of SOM values with established erosion severity classes [46]. Whilst SOM remains a candidate without substitute as long as a one-parameter indicator of soil degradation is needed, narrowing down to the use of its labile and microbial components could be more appropriate, since early detection is important in the control and management of soil degradation.

\section{CONClusions}

SOM and SOC has proven vital for soil aggregate stability and soil health. Maintaining important levels of SOM and SOC are primordial for maintaining stable and healthy soils. SOM and SOC are intrinsically linked to SDG $1,2,8,13$ and 15. Maintaining acceptable levels of SOC is also important for enhancing carbon sequestration and climate change mitigation as pathways towards achieving 
SDG 13. For the soil as a resource-base to humankind fully contributes to the achievement of sustainable development goals, acceptable SOC and SOM levels are needed to be maintained through sustainable land management strategies that reverse degrading soils and maintain fertility and soil carbon sink capacity. The principles of sustainable land management practices laid down by SDG 15.3 are aimed at reversing land degradation and thriving for a land degradation neutral world by 2030. Sustainable grazing, limiting transhumance and grassland burning are amongst the recommended strategies to reverse continuous degradation of the degrading areas and improvement upon the quality of non-degraded but vulnerable lands over the plateau.

\section{ACKNOWLEDGEMENT}

The authors are grateful for the financial support for data collection and treatment by the International Association for Mathematical Geosciences (IAMG) Computers and Geosciences Research Scholarship (CG-2020-9), for the 2020/2021 academic year.

\section{REFERENCES}

[1] Z. N. Fogwe, "Landscape Degradation on the Kom Highlands (N.W Province, Cameroon): An Environmental Assessment," Doctorat de 3e Cycle Thesis, Dept. Geog., Univ., Yaoundé I, Cameroon, 1997.

[2] FAO, ITPS, "Status of the World's Soil Resources (SWSR) - Main Report," Food and Agriculture Organization of the United Nations and Intergovernmental Technical Panel on Soils, Rome, Italy, 2015.

[3] S. Keesstra, G. Mol, J. de Leeuw, J. Okx, C. Molenaar, M. de Cleen, and S. Visser, "Soil-Related Sustainable Development Goals: Four Concepts to Make Land Degradation Neutrality and Restoration Work," 2018, Land, 7, 133. doi:10.3390/land7040133.

[4] J. S. C. Mbagwu, (2003). "Aggregate Stability and Soil Degradation in the Tropics", 2003. http://users.ictp.it/\%7Epub_off/lectures/lns018/22Mbagwu1.pdf.

[5] R. Lal, A. Wagner, D. J. Greenland, T. Quine, D. W. Billing, R. Evans, K. Giller, "Degradation and Resilience of Soils", 1997, Philos. Trans. R. Soc., 352: 1356, 997-1010.

[6] R. Lal, "Soil Erosion and Land Degradation: The Global Risks," in Advances in Soil Science, R. Lal, and B. A. Stewart, Ed. SpringerVerlag New York Inc, 1990, pp. 129-172.

[7] P. Laban, G. Metternicht, J Davies, "Soil Biodiversity and Soil Organic Carbon: keeping drylands alive," Gland, Switzerland: IUCN, 2018, viii $+\quad 24$ pages, https://doi.org/10.2305/IUCN.CH.2018.03.en.

[8] J. Chen, J-Z. Chen, M-Z. Tan, Z-T. Gong, "Soil degradation: a global problem endangering sustainable development," 2002, J. Geogr. Sci., vol. 12, 2, pp. 243-252.

[9] IRP, "Land Restoration for Achieving the Sustainable Development Goals: An International Resource Panel Think Piece," J. E. Herrick, T. Abrahamse, P. C. Abhilash, S. H. Ali, P. Alvarez-Torres, A. S. Barau, C. Branquinho, A. Chhatre, J. L. Chotte, A. L. Cowie, K. F. Davis, S. A. Edrisi, M. S. Fennessy, S. Fletcher, A. C. Flores-Díaz, I. B. Franco, A. C. Ganguli, C. I. Speranza, M. J. Kamar, A. A Kaudia, D. W. Kimiti, A. C. Luz, P. Matos, G. Metternicht, J. Neff, A. Nunes, A. O. Olaniyi, P. Pinho, E. Primmer, A. Quandt, P. Sarkar, S. J. Scherr, A. Singh, V. Sudoi, G. P. von Maltitz, L. Wertz, G. A. Zeleke, think piece of the International Resource Panel. United Nations Environment Programme, Nairobi, Kenya.

[10] Gomiero T, "Soil Degradation, Land Scarcity and Food Security: Reviewing a Complex Challenge," Sustainability, vol. 8, 3, 281; https://doi.org/10.3390/su8030281.

[11] H, Eswaran, R. Lal, P. F. Reich, "Land degradation: an overview," in Responses to Land Degradation. Proc. 2nd. Proceedings of International Conference on Land Degradation and Desertification, E. M. Bridges, I. D. Hannam, L. R. Oldeman, F. W. T. Pening de Vries, S. J. Scherr, S. Sompatpanit, Ed. Khon Kaen, Thailand. Oxford Press, New Delhi, India, 2001.
[12] O. J. Idowu, "Relationships between aggregate stability and selected soil properties in humid tropical environments," 2003, Commun Soil Sci Plant Anal, 36, pp. 695-708.

[13] B. Wang, F. Zheng, M. J. M. Römkens, "Comparison of soil erodibility factors in USLE, RUSLE2, EPIC and Dg models based on a Chinese soil erodibility database," 2013, Acta Agric Scand B Soil Plant Sci, vol. 63, 1 pp. 69-79, http://dx.doi.org/10.1080/09064710.2012.718358.

[14] C. M. Lambi, The impacts of human activities on land degradation in some highland regions of Cameroon: implications for development," in Environmental Issues, Problems and Prospects, Unique Printers, Bamenda, 2001, pp. 45-66.

[15] S. S. Kometa, A. E. M. Tambe, "Watershed Degradation in the Bamendjin Area of the North West Region of Cameroon and Its Implication for Development," 2012, J. Sustain. Dev, vol. 5, 9, pp. 75-84.

[16] E. Achankeng, M. R. Fokeng, "Montane Forest Loss and Watershed Degradation: Case of the Tubah Uplands of the North West Region of Cameroon," 2015, Afr J Special Educ, vol. 3, 1.

[17] C. G. Kometa, "Drivers of Watershed Degradation and its Implications on Potable Water Supply in the Menchum River Basin of Cameroon," 2019, World J of Social Sci, Research, vol. 6, 4, pp. 483-502.

[18] Z. N. Fogwe, M. Tchotsoua, "Ecological Adaptability and SlopeTrait Considerations for Water and Soil Conservation on the Vulnerable Oku-Kom Plateau in the Western Highland of Cameroon," 2010, J Hum Ecol, vol. 30, 1, pp. 19-25.

[19] P. Tchawa, "La dégradation des sols dans le Bamiléké méridional conditions naturelles et facteurs anthropologiques," 1993, Cahiers d'outre-mer, $\mathrm{N}^{\circ} 181$ - 46e, pp. 75-104.

[20] J. D. Ngandeu-Mboyo, M. Yemefack, R. Yongue-Fouateu, P. Bilong, "Erodibility of cultivated soils in the Foumbot Area (West Cameroon)," 2016, Tropicultura, vol. 34, 3, pp. 276-285.

[21] P. A. Tamfuh, A. H. Chotangui, V. Y. Katte, R. A. Achantap, A. M. Magha, D. E. Moundjeu, F. O. Tabi, D. Bitom, "Land Characteristics and Agricultural Suitability Status along a Toposequence in Santa, Bamenda Highlands, Cameroon," 2020, HSOA J. Atmos. \& Earth Sci.,, vol. 4: 022. DOI: 10.24966/AES-8780/100022.

[22] S. J. T. Tume, "Indigenous adaptation to climate variability of rainfed agro-hydrological systems in the Bui Plateau, North West Region, Cameroon," PhD Thesis, Dept of Geog. and Plan, Univ. Bamenda, Cameroon, 2019.

[23] P. Hawkins, Brunt M, "West Cameroon (Bamenda area soils)," 1965, https://esdac.jrc.ec.europa.eu/content/west-cameroonbamenda-area-soils. Accessed on 27/10/2020.

[24] FAO, "Measuring and modelling soil carbon stocks and stock changes in livestock production systems: Guidelines for assessment (Version 1), Livestock Environmental Assessment and Performance (LEAP) Partnership," FAO, Rome, 2019.

[25] A. Walkley, I. A. Black, "An examination of the Degtjareff method for determining soil organic matter, and a proposed modification of the chromic acid titration method," 1934, Soil Sci, 37, pp. 29-38.

[26] . Kumar, N. K. Sinha, "Geostatistics: Principles and Applications in Spatial Mapping of Soil Properties," in Geospatial Technologies in Land Resources Mapping, Monitoring and Management, Geotechnologies and the Environment, G. P. O. Reddy, S. K. Singh Ed. 2018, 21, pp. 143-159. https://doi.org/10.1007/978-3-319-787114_8.

[27] A. D. Hartkamp, K. De Beurs, A. Stein, J. W. White, "Interpolation techniques for climate variables. NRG-GIS series," 99-01. Mexico City: CIMMYT, 1999.

[28] A. Almajmaie, M. Hardie, R. Doyle, R. B. Colin, T. Acuna, "Influence of soil properties on the aggregate stability of cultivated sandy clay loams," 2017, J Soils Sediments, vol. 17, pp. 800-809. https://doi.org/10.1007/s11368-016-1568-1.

[29] M. Olaniya, P. K. Bora, S. Das, P. H. Chanu, "Soil erodibility indices under different land uses in Ri-Bhoi district of Meghalaya (India)," 2020, Sci Rep, vol. 10, 14986, https://doi.org/10.1038/s41598-020-72070-y.

[30] C. Pieri, "Fertility of Soils: A Future for Farming in the WestAfrican Savannah," Springer, Berlin, 1991.

[31] W. H. Wischmeier, D. D. Smith, Predicting rainfall erosion losses, a guide to conservation planning. United States Department of Agriculture Agricultural Handbook No. 537, Washington, DC: U.S. Government Printing Office, 1978.

[32] K. G. Renard, G. R. Foster, G. A. Weesies, D. K. McCool, D. C Yoder, Prediction rainfall erosion by water, a guide to conservation planning with the Revised Universal Soil Loss Equation (RUSLE), USDA Agricultural Handbook No. 703. Washington, DC: U.S Government Printing Office, 1997. 
[33] H. H. Bennett, "Some comparisons of the properties of humidtropical and humid-temperate American soils; with special reference to indicated relations between chemical composition and physical properties," 1926, Soil Sci. vol. 21, 5, pp. 349-376.

[34] P. R. Bryan, "Measures of the degree of chemical weathering of rocks,"1968, J. Geol. 76, pp. 518-527.

[35] K. Kumar, S. K. Tripathi, K. S. Bhatia, "Erodibility characteristics of Rendhar watershed soils of Bundelkhand," 1995 Indian J. Soil Conserv. 23, pp. 200-204.

[36] A. N. Sharply, J. R. Williams, EPIC-Erosion/Productivity Impact Calculator I, model documentation. U.S. Department of Agriculture Technical Bulletin, No. 1768. (Washington, DC: USDA Agricultural Research Service), 1990.

[37] C. Pieri, "Fertilité des Terres de Savane. Bilan de Trente Ans de Recherche et de Développement Agricoles au Sud du Sahara," Ministère de la Coopération/Cirad, Paris, 1989.

[38] B. Wang, F. Zheng, Y. Guan, "Improved USLE-K factor prediction: A case study on water erosion areas in China," 2016, Int Soil \& Water Cons Res, vol. 4, pp. 168-176, http://dx.doi.org/10.1016/j.iswcr.2016.08.003.

[39] W. H. Wischmeier, C. B. Johnson, B. V. Cross, "A soil erodibility nomograph for farmland and construction sites," 1971, J. Soil \& Water Cons., vol. 26, 5, pp.189-193.

[40] Z. N. Fogwe, "The Ndop Sabga Great Erosional Arc: Physical Milieu, Land Use and Erosional Risks," Maîtrise Dissertation, Dept Geog., Univ. of Yaoundé I, 1990.

[41] Y. Le Bissonnais, D. Arrouays, "Aggregate stability and assessment of soil crustability and erodibility, II. Application to humic loamy soil with various organic carbon contents," 1997, European J of Soil Sci, 48, pp. 39-48.

[42] E. T. Elliott, (1986). "Aggregate structure and carbon, nitrogen and phosphorus in native and cultivated soils," 1986, Soil Science Society of America Journal, 50, pp. 627-633.

[43] A. Golchin, P. Clarke, J. M. Oades, J. O. Skjemstad, "The effects of cultivation on the composition of organic-matter and structural stability of soils," 1996 Australian Journal of Soil Research, 33, pp. 975-993.

[44] M. J. M. Römkens, C. B. Roth, D. W. Nelson, "Erodibility of selected clay subsoils in relation to physical and chemical properties," 1997, Soil Sci Soc Am J, 41, pp. 954-960.

[45] J. S. C. Mbagwu, U. "Schwartzman, Some factors affecting clay dispersion and aggregate stability in selected soils of Nigeria," 2006, Int Agrophys, vol. 20, pp. 23-30.

[46] S. Obalum G. Chibuike S. Peth, Y. Ouyang, "Soil organic matter as sole indicator of soil degradation," 2017, Environ. Monit. Assess, vol. 189, 176. https://doi.org/10.1007/s10661-017-5881-y.

[47] W. H. Wischmeier, J. H. Mannering, "Relation of soil properties to its erodibility. 1969 Soil Science Society of America Proceedings," 33, pp. 131-137.

[48] M. Conforti, G. Buttafuoco, A. P. Leone, P. P. C. Aucelli, G. Robustelli, F. Scarciglia. (2013). "Studying the relationship between water induced soil erosion and soil organic matter using Vis-NIR spectroscopy and geomorphological analysis: a case study in southern Italy," 2013, Catena, vol. 110, pp. 44-58.

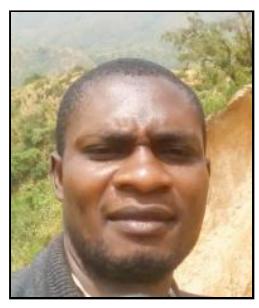

Reeves M. Fokeng holds a Bachelor of Arts, and a Master's Degree in Geography (Geomorphology \& Remote Sensing) from University of Dschang, Cameroon. He is currently pursuing a Ph.D in GIS and Remote Sensing in Planning, at the Department of Geography and Planning, Faculty of Arts, The University of Bamenda, Cameroon. He currently occupies a temporal assistant teaching and research position with the Department of Geography and Planning in the domains of remote sensing and GIS, cartography and physical geography. His research spans across modeling earth surface processes dynamics, land change science, and human interactions, and applied remote sensing and GIS. He has published over a dozen of articles in internationally peer-reviewed journals. Mr Fokeng has acted as invited reviewer to several international journals including; International Journal of Environment and Climate Change, Journal of Geography, Environment and Earth Science International, Asian Journal of Environment \& Ecology, Net Journal of Agriculture, Springer Folia Geobotanica etc.

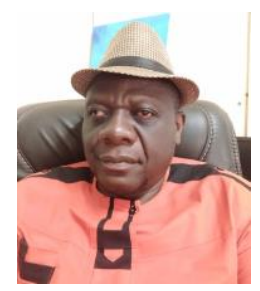

Zephania N. Fogwe holds a Bachelor of Arts, Maitise, Diplome d'Etudes Approfondi, Doctorat de 3e Cycle in Geography from University of Yaounde 1 in Cameroon. At the University of Buea, Cameroon, he obtained a Ph.D in Geography. He has lectured in pure and applied physical geographies being his focus in research and publications in books and journals. He is a Full Professor of Applied Geomorphology/Development and Environmental Assessment. His teaching and research focus is on pure and applied physical geographies. He has over seventy publications in books and peer-reviewed journals at the national and international levels, also serving as editorial board member in many. Formerly serving at the Office of Academic Affairs of The University of Bamenda, he deputizes at the Laboratory of Environment, Hazards and Sustainable Development of the Doctoral Unit in Geography, History and Heritage, Faculty of Arts, University of Douala where he had served as Vice Dean. Prof Fogwe is an editorial board member of several renowned national and international journals, a development and environmental consultant. He is member to national and international scientific bodies of common interest. He was the pioneer Chair of the Department of Geography and Planning, Faculty of Arts at the University of Bamenda where he is Director of Development, Physical Plant, and Infrastructure.

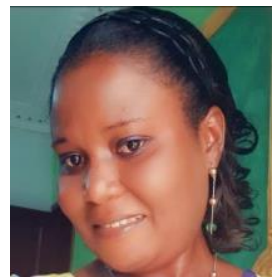

Nadine T. Yemelong holds a Bachelor of Arts, Master's Degree and Ph.D. in Geography from University of Dschang, Cameroon. She is Senior Lecturer with the Department of Geography, Higher Teacher Training College (HTTC), The University of Bamenda, Cameron. Dr Yemelong is currently serving as Head of Department of Customs at the Higher Institute of Transport and Logistics (HITL), The University of Bamenda. Dr Yemelong lectures in human geographies, Geographic Information Systems (GIS) and remote sensing being her focus in research and publications. 